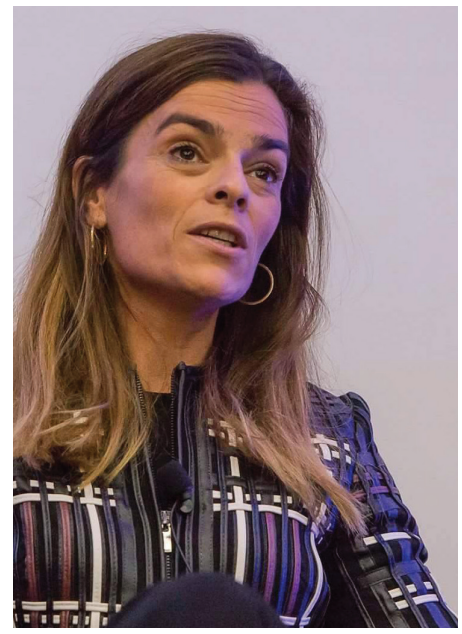

\title{
Medicina Centrada no Doente
}

\section{Patient-Centered Medicine}

\author{
Cláudia de Lemos Silveira
}

A Gazeta Médica está em movimento ascendente, com dinamismo e capacidade de atração de artigos originais, revisões e casos clínicos de grande qualidade. A presença de trabalhos que demonstram a importância de cuidados de saúde baseados na entrega de valor são predominantes, onde a capacidade de diagnóstico e tratamento de patologias cada vez mais complexas e as necessidades de cada doente se encontram no centro do exercício da medicina.

O sexto número da Gazeta Médica revela um conjunto de trabalhos desenvolvidos de forma integrada por equipas multidisciplinares, da relevância da discussão de casos clínicos e da organização dos cuidados de saúde orientados à doença e ao doente.

O artigo "Abordagem sistémica de tolerância ao exercício: um caso para modelação matemática" apresenta um modelo matemático adaptado e desenvolvido pelos autores para a prescrição de exercício físico, dada a importância de antecipar a tolerância ao esforço físico de cada indivíduo. O artigo conclui com a oportunidade existente na criação de um núcleo de investigação em medicina desportiva com inclusão da modelação matemática em sistemas dinâmicos.

O Instituto CUF de Oncologia apresenta dois artigos originais, o primeiro sobre os primeiros casos tratados em Portugal em recidivas locorregionais com recurso à radioterapia e hipertermia, e o segundo com uma síntese da casuística tratada na unidade de Oncologia pulmonar do Hospital CUF Porto entre 2014 e 2016 e a comparação com o seu referencial nacional.

São ainda apresentados casos clínicos diversos onde é evidente a importância do trabalho multidisciplinar e em equipa na obtenção de melhores outcomes clínicos.

Fecho o editorial com referência ao primeiro artigo de perspetiva sobre os Cuidados Pediátricos em São Tomé e Príncipe que nos transportam para uma prática médica diferente da que experienciamos nos países europeus, onde existem desafios e necessidades dada a escassez de recursos médicos diferenciados e onde temas como a criação de valor têm um significado bem distinto face aos que discutimos no mundo mais desenvolvido. 